Available online on 15.7.2018 at http://ujpr.org
Universal Journal of Pharmaceutical Research
An International Peer Reviewed Journal
Open access to Pharmaceutical research is an open access article distributed under the terms of the Creative Commons Attribution-Non
Commercial Share Alike 4.0 License which permits unrestricted non commercial use,
provided the original work is properly cited
Volume 3, Issue 3, 2018

\title{
PRESCRIPTION PATTERN OF ANTI-HYPERTENSIVE DRUGS IN A TERTIARY CARE HOSPITAL IN KERALA AND ADHERENCE TO JNC-8 GUIDELINES

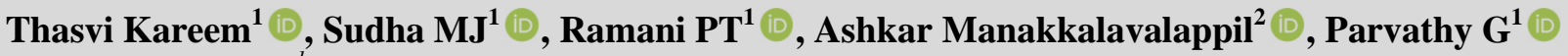 \\ ${ }^{\prime}$ Department of Pharmacology, Azeezia medical college, Kollam, Kerala, India.
} \\ ${ }^{2}$ Department of Pulmonary Medicine, Azeezia medical college, Kollam, Kerala, India.
}

\section{ABSTRACT}

Objective: Hypertension is a leading contributor to the global burden of cardiovascular morbidity and mortality. Worldwide prevalence is continuing to increase. Treatment for hypertension is constantly evolving and many new drugs are added at rapid pace. The objective of this study is to investigate utilization pattern of antihypertensive drugs in hypertensive patients in Azeezia institute of Medical Sciences and Research and to find its adherence to JNC-8 guidelines for management of hypertension.

Methods: Descriptive drug utilization study was conducted on 266 hypertensive patients for period of 3 months. Data retrieved from patient's medical record. The study included all hypertensive patients with or without co-morbidities and above 18 yrs who attended out-patient department. Following classes of antihypertensive drugs were analyzed: Angiotensin Converting Enzyme Inhibitors (ACEI), Angiotensin Receptor blockers (ARB), beta blockers, calcium channel blockers, diuretics. ACEI/ARB was mostly prescribed which is in adherence to JNC-8 guidelines which recommends the use of ACEI/ARB as the first choice of drug. Results: Hypertension is more prevalent in males than in females. ACEI/ARB are the most frequently prescribed classes of drugs alone or in combination, supporting the medication adherence to JNC-8 guidelines.

Conclusion: The study concludes that the hypertension is more prevalent in males than in females, with its prevalence increasing with age.

Keywords: Antihypertensive drugs, drug utilization, hypertension, JNC-8 guidelines, prescription pattern.

Article Info: Received 27 March 2018; Revised 24 May; Accepted 29 June, Available online 15 July 2018

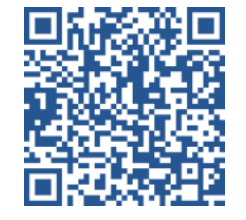
Cite this article-

Kareem T, Sudha MJ, Ramani PT, Manakkalavalappil A, Parvathy G. Prescription pattern of anti-hypertensive drugs in a tertiary care hospital in Kerala and adherence to JNC-8 guidelines. Universal Journal of Pharmaceutical Research 2018; 3(3): 1-3.

DOI: https://doi.org/10.22270/ujpr.v3i3.158

Address for Correspondence

Thasvi Kareem, Department of Pharmacology, Azeezia medical college, Kollam, Kerala, India. E-mail: talk2thanu@gmail.com

\section{INTRODUCTION}

Hypertension is a leading contributor to the global burden of cardiovascular morbidity and mortality. Worldwide prevalence of hypertension is estimated to be as large as one billion and its prevalence is predicted to increase by approximately $60 \%$ by 2025 . It varies from $4-15 \%$ in urban and $2-8 \%$ in rural population ${ }^{1}$. Apart from unhealthy lifestyles, lack of awareness, distorted public health systems, physicians also lag behind in giving treatment according to standard guidelines. Noncompliance to antihypertensive therapy is also a reason for uncontrolled hypertension. Hypertension is now a strongest modifiable risk factor for myocardial infarction, stroke, heart failure, chronic kidney diseases and retinopathy ${ }^{2}$. Treatment of hypertension is constantly evolving in response to new evidence published and newer drugs are added at rapid pace. The resultant changes in drug use in time and place may have medical, social and economic implications both for individual patient and for populations ${ }^{3,4}$. Recommendations of various guidelines are available for their treatment, one such guideline is JNC 7 which recommends the rationale administration of drugs by providing algorithms for the treatment as per stages of hypertension ${ }^{5}$. Hypertension is divided into four categories: normal, prehypertension, stage 1 HTN and stage $2 \mathrm{HTN}^{6,7,8}$. JNC8 recommended four medication classes for Hypertension treatment in the general population with thiazide-type diuretics being first line therapy. Recommended classes are thiazidetype diuretics, calcium channel blockers, angiotensincovering enzyme inhibitors and angiotensin receptor blockers ${ }^{6}$. This study was designed to assess the current trend of the prescription pattern of antihypertensive drugs and to determine the adherence to JNC8 guidelines ${ }^{9,10}$. This kind of medical audit can help to make prescription pattern more rational and prudent and thereby improve patient health care. 


\section{MATERIALS AND METHODS}

The observational, prospective study was carried out at Azeezia Medical Hospital, Kollam. Data of drug prescribed were taken from patient's medical record. The study was approved by Institutional Human Ethical Committee of Azeezia Institute of Medical Sciences and Research, Kollam

Study design: This study was observational prospective conducted over 3 months period from May 2016 to July 2016 for assessing prescription pattern and drug utilization of antihypertensive in the management of hypertension and its adherence to JNC8 Guidelines. Total of 266 patients were included into study.

Study setting: The study was carried out in the outpatient department of Azeezia Medical Hospital, Kollam for collection of data.

Study Population: The study included all hypertensive patients.

Inclusion criteria: were 1) Age above 18 years, 2) Patients with co- morbidities such as Diabetes, risk of cardiovascular disease, Chronic Kidney diseases and Bronchial Asthma.

Exclusion criteria: were patients with terminal illness. Data Collection:

All necessary and relevant information patient and drugs prescribed were collected from patient's medical records. The data were filled in the Performa prepared which was approved by the Institutional Ethics Committee. The JNC8 Guidelines for the adherence were studied by taking into consideration that the drugs recommended as the first line therapy by JNC8 should be the most frequently prescribed class of drugs and should have high utilization pattern among the patients. Statistical Data Analysis:

The data was analysed using SPSS software. A P value $\leq 0.05$ was declared as statistically significant.

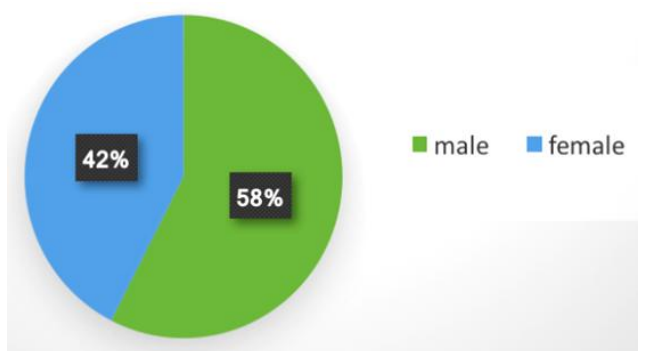

Figure 1: Number of patient in each sex groups.

\section{RESULTS}

The results of this analysis shows that out of 266 hypertensive patients included, $57.5 \%$ were males while remaining $42.5 \%$ were females. This indicates the more number of patients with hypertension were males. Total $42.9 \%$ of people and $54.5 \%$ of hypertensive patients were from age group between 4565 years and above 65 years respectively. Only 7 patients out of $266(2.6 \%)$ were from age group less than 45 years. This data suggest age as the risk factor for hypertension. Out of 266, 78.2\% of hypertensive patients were found to have other co-morbid conditions. Among the total 208, maximum patients were having diabetes mellitus followed by cardiovascular and kidney disease.

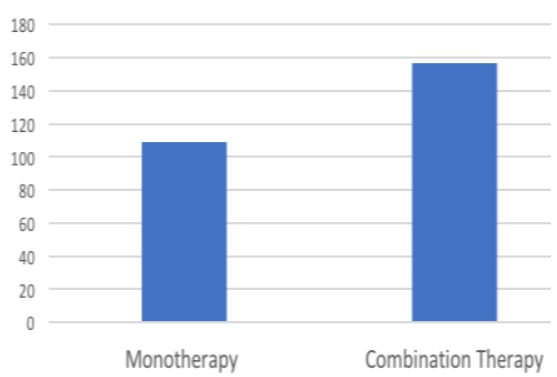

Figure 2: Type of therapy taken by hypertensive patients.

Considering out of the total 266 patients, 109(40.9\%) patients received monotherapy while the remaining were put on multidrug regimen. $95(35.8 \%)$ patients were on 2 drug therapy and 62(23.3\%) were on 3 drug regimen.

Table 1: Age Distribution of patient.

\begin{tabular}{lcc}
\hline $\begin{array}{c}\text { Age Groups } \\
\text { (Years) }\end{array}$ & $\begin{array}{c}\text { Number of } \\
\text { patient } \\
(\mathbf{n = 2 6 6 )}\end{array}$ & $\begin{array}{c}\text { \% of } \\
\text { patient in } \\
\text { each group }\end{array}$ \\
\hline Below 45 & 7 & 26 \\
years & & \\
45-65 years & 114 & 42.9 \\
Above 65 & 145 & 54.5 \\
years & & \\
\hline
\end{tabular}

Among the monotherapy, maximum patients were on ARB/ACEI with $31.2 \%$ followed with calcium channel blockers with $5.6 \%$ and diuretic $(4.1 \%)$. As a monotherapy Losartan was the most frequently prescribed drug along with thiazides and metopropolol. The prescription pattern of antihypertensives (ACEI/ $\mathrm{ARB}$ ) were found to be considerately in adherence to Eighth report of Joint National Committee (JNC 8) for prevention, detection, evaluation and treatment of hypertension, which recommends that the choice of treatment for initial hypertension should be ACEI/ ARBS, thiazides, CCBs, BBs alone or in combination may also be preferred. Interview of patients or their representatives suggested that patient compliance to the medication was moderate and was better in females when compared to males.

Table 2: Distribution of patients with comorbidities.

\begin{tabular}{lcc}
\hline $\begin{array}{c}\text { Co- } \\
\text { morbidities }\end{array}$ & $\begin{array}{c}\text { Number of } \\
\text { patient } \\
(\mathbf{n = 2 0 8})\end{array}$ & $\begin{array}{c}\text { Percentage } \\
\text { distribution }\end{array}$ \\
\hline Diabetes & 101 & 48.5 \\
CVD & 64 & 31.2 \\
CKD & 43 & 20.6 \\
\hline
\end{tabular}

\section{DISCUSSION}

The results of this study suggest that hypertension is more in male, compared to females. A previous study reported that there was higher incidence of hypertension in females than in males in Germany ${ }^{3}$.

This study also reveals that hypertension is more prevalent in elderly patients belonging to age groups 
45-65 or more. It also shows that most frequently prescribed classes of drugs were ACEI/ARB alone or in combination. Since the eighth report of Joint National Committee (JNC8) on detection, evaluation prevention and treatment recommends the use of ACEI/ARB for management of early stage hypertension alone or in combination with other classes, thus suggesting that the above trends is in conformity to the recommendations of JNC 8 guidelines.

Table 3: Utilization pattern of antihypertensive as monotherapy.

\begin{tabular}{lcc}
\hline Drug & $\begin{array}{c}\text { Number of } \\
\text { patients } \\
(\mathbf{n = 1 0 9 )}\end{array}$ & $\begin{array}{c}\text { Percentage } \\
\text { Distribution }\end{array}$ \\
\hline ARB/ & 83 & 31.2 \\
ACEI & & 4.1 \\
\hline Diuretics & 11 & 5.6 \\
$\begin{array}{l}\text { Calcium } \\
\text { channel } \\
\text { blockers }\end{array}$ & 15 & \\
\hline
\end{tabular}

Hence this drug utilization data corroborated adherence to JNC 8 guidelines. Among the 2 drug regimen Diuretics + ACEI/ ARBSs is the most widely prescribed regimen, while ACEIs/ARBs ${ }^{+} \mathrm{CCBs}^{+}$Diuretics was the most frequently prescribed three drug regimens.

Table 4: Utilization pattern of antihypertensive class of drugs.

\begin{tabular}{lcc}
\hline \multicolumn{1}{c}{$\begin{array}{c}\text { Type of } \\
\text { treatment }\end{array}$} & $\begin{array}{c}\text { Number of } \\
\text { patients }\end{array}$ & $\begin{array}{c}\text { Percentage } \\
\text { Distribution }\end{array}$ \\
\hline $\begin{array}{l}\text { Mono } \\
\text { therapy }\end{array}$ & 109 & 40.9 \\
\hline $\begin{array}{l}\text { 2 Drug } \\
\text { Combination }\end{array}$ & 95 & 35.8 \\
\hline 3 Drug & 62 & 23.3 \\
Combination & & \\
\hline
\end{tabular}

\section{CONCLUSION}

The study concludes that the hypertension is more prevalent in males than in females, with its prevalence increasing with age. ACEIs/ARBs are the most frequently prescribed classes of drugs alone or in combination, supporting the adherence to JNC guidelines. Since the prevalence of hypertension depends upon ethnicity, genetic, environmental and physiological factors, further research is critically needed to set up a rationale or pattern for the choice of medication; on the basis of above mentioned factors.

\section{ACKNOWLEDGEMENTS}

The authors extend their thanks and appreciation to the Azeezia medical college, Kollam, Kerala, India to provide necessary facilities for this work.

\section{AUTHOR'S CONTRIBUTION}

The manuscript was carried out, written, and approved in collaboration with all authors.

\section{CONFLICT OF INTEREST}

We declare that we have no conflict of interest.

\section{REFERENCES}

1. Johnston A, Stafylas P and Stergiou GS. Effectiveness, safety and cost of drug substitution in hypertension; Brithish J Clin Pharmacol 2010; 70(1): 320-334. https://doi.org/10.1111/j.1365-2125.2010.03681.x

2. Kearney PM, Whelton M, Reynolds K, Muntner P. Global burden of hypertension: analysis of worldwide data; Lancet 2005; 36(5): 217-223. https://doi.org/10.1016/S0140-6736(05)17741-/

3. Khan N A, Hemmelgarn B, Herman RJ, Rabkin SW, et al. Canadian Hypertension education Program Recommendations for the Management of Hypertension: Part 2 Therapy. Can J Cardiol 2008; 24(6): 465-75. https://doi.org/10.1016/s0828-282x(08)70620-2

4. Sharminder K, Seema G, Dinesh K, Mohan L, Zahid G. Prescription pattern of antihypertensive drugs in a tertiary care hospital in Jammu- A descriptive study; JKPractitioner 2012; 17(4):38-41.

5. JNC8hypertensionalgorithm:http://www.nmhs.net/docume nts/27JN C8HTN Guidelines Book; accessed on 29 March 2016.

6. Kayce B, June T, Bernie RO: Hypertension-the silent killer, updated JNC8 guideline recommendations; Summer 2015-continuing education/www.aparx.com accessed on 29 march 2016.

7. Al-Mehdar AA, Al-Akydy AG. Pattern of antimicrobial prescribing among in-patients of a teaching hospital in Yemen: a prospective study. Universal J Pharm Res 2017; 2(5): 10-14. http://doi.org/10.22270/ujpr.v2i5.R

8. Yazdanpanah A, Boushehri LB, Vahdat S. Comparison of the knowledge, attitude and performance of hospital managers in Bushehr province about nosocomial infections. Universal J Pharm Res 2018;3(2):1-5. https://doi.org/10.22270/ujpr.v3i2.128

9. Abbas Y, Marjan Y, Parviz AB. Identification and prioritization of barriers to implement the Green hospital standards at Imam Hassan Mojtaba hospital in Darab. Universal J Pharm Res 2018;3(1):43-48. http://doi.org/10.22270/ujpr.v3i1.R8

10. Vahdat S, Hessam S, Dadashi J. The impact of hospital information system on the working process of Imam Ja'far Sadiq hospital, Alborz province -2016. Universal J Pharm Res 2018;3(1):7-11.

http://doi.org/10.22270/ujpr.v3i1.R2 